\title{
DYNAMICS AND FORECASTING OF POPULATION GROWTH AND URBAN EXPANSION IN SRINAGAR CITY - A GEOSPATIAL APPROACH
}

\author{
Majid Farooq ${ }^{a} *$, Mohammad Muslim ${ }^{b}$ \\ ${ }^{a}$ Department of Ecology, Environment and Remote Sensing, SDA Colony Bemina, Srinagar, J\&K, India - 190018. \\ majid_rsgis@yahoo.com \\ ${ }^{\mathrm{b}}$ Division of Environmental Sciences, SKUAST-K Shalimar, J\&K, India - 191121. \\ muslim_rsgis@yahoo.co.in
}

\section{ISPRS TC VIII}

KEY WORDS: Urban, Sprawl, Population, Regression, Temporal

\begin{abstract}
:
The urban areas of developing countries are densely populated and need the use of sophisticated monitoring systems, such as remote sensing and geographical information systems (GIS). The urban sprawl of a city is best understood by studying the dynamics of LULC change which can be easily generated by using sequential satellite images, required for the prediction of urban growth. Multivariate statistical techniques and regression models have been used to establish the relationship between the urban growth and its causative factors and for forecast of the population growth and urban expansion. In Srinagar city, one of the fastest growing metropolitan cities situated in Jammu and Kashmir State of India, sprawl is taking its toll on the natural resources at an alarming pace. The present study was carried over a period of 40 years (1971-2011), to understand the dynamics of spatial and temporal variability of urban sprawl. The results reveal that built-up area has increased by $585.08 \%$ while as the population has increased by $214.75 \%$. The forecast showed an increase of $246.84 \mathrm{~km}^{2}$ in built-up area which exceeds the overall carrying capacity of the city. The most common conversions were also evaluated.
\end{abstract}

\section{INTRODUCTION}

Urban sprawl is the outgrowth of built-up along the periphery of cities and along highways. Although an accurate definition of urban sprawl is a subject of debate, however, a consensus is that urban sprawl is characterized by an unplanned pattern of growth, driven by a multitude of processes and leading to inefficient utilization of resources. Rapid urbanization poses considerable social and environmental challenges to city authorities and planners (Sudhira et al. 2004). Uncontrolled population growth, economic disparities and poverty all increase the potential of sprawl. Poor urban planning and housing development lead to construction of informal settlements that lack access to basic infrastructure and provide poor living conditions. Consequently, increase in unregulated traffic, noise, and underdeveloped sewage and waste management cause further environmental degradation (Zeug and Eckert 2010). Close monitoring of rapid urbanization is crucial for the creation of sustainable urban environments. Monitoring urban development is mainly to find the type, amount and the location of land conversion for future planning (Shekhar 2004). The built-up and impervious surfaces are generally considered as the parameter of quantifying urban sprawl (Torrens and Alberti 2000, Barnes et al. 2001, Epstein et al. 2002, Jothimani 1997). The study on urban sprawl is attempted in the developed countries (Batty et al. 1999, Torrens and Alberti 2000, Barnes et al. 2001, Hurd et al. 2001, Epstein et al. 2002) and recently in developing countries such as China (Yeh and Li 2001, Cheng and Masser 2003) and India (Jothimani 1997, Lata et al. 2001, Sudhira et al. 2004). Morphological measurement of urban development is important for land use planning and the study development (Webster
1995, Shen 2002). Geographical Information System (GIS) and remote sensing are very useful in the formulation and implementation of the spatial and temporal changes, which are essential components of regional planning to ensure the sustainable development. Various analysts have made considerable progress in quantifying the urban sprawl pattern (Theobald 2001, Lata et al. 2001, Torrens and Alberti 2000, Batty et al, 1999). The spatial patterns of urban sprawl over different time periods can be systematically detected, mapped, and analyzed using remote sensing and GIS data along with conventional ground data (Barnes et al. 2001, Lata et al. 2001). Remote sensing has been used to monitor this urban development, similar research has been carried out elsewhere by Howard (1986), Fung and LeDrew (1987), Li and Yeh (1998) and various techniques have been developed for urban growth detection efficiency, including image differencing (Toll 1980), Image rationing (Nelson 1983), Masking Method (Pilon et al. 1988) and principal component analysis (Fung and LeDrew 1987, Li and Yeh 1998). Urban expansion is driven by population growth, social and economic development (Liu et al. 2002, Wilson et al. 2003). Typically, empirical approaches use regression methods to quantify models from data that describe the spatial and historic distribution of land use and population changes. There are many examples of empirical models based on regression methods (Veldkamp and Fresco 1996, deKoning et al. 1998, Pontius and Schneider 2001, Serneels and Lambin 2001). The statistical models implemented possess a sufficiently general form that they can be implemented wherever LULC is of interest to policy makers. Because land use change is usually represented as a discrete change (for example, from agricultural land to scrubland or to other land use class), logistic (both binary and multinomial) regression is an appropriate statistical

\footnotetext{
* Corresponding author. This is useful to know for communication with the appropriate person in cases with more than one author.
} 
model to use (Trexler and Travis 1993). However, there is a general lack of research on the development of methods and indicators to quantify and study urban expansion (Dendoncker et al. 2008) and less attention has been paid to long time series urban expansion and morphological pattern of urban expansion in the Srinagar City.

In the current study urban growth patterns of Srinagar city were mapped using time series of satellite and population census data from the period between 1971 and 2011. After careful review of different studies, the present study was undertaken with a primary objective to map the spatial extent of the city over the period of time and forecast the urban sprawl and population growth using appropriate regression models.

\section{STUDY AREA}

Srinagar city the summer capital of Jammu and Kashmir, lies between $34^{\circ} 0{ }^{\prime} \mathrm{N}$ to $34^{\circ} 15^{\prime} \mathrm{N}$ latitude and $74^{\circ} 45^{\prime} \mathrm{E}$ to $74^{\circ} 0^{\prime} \mathrm{E}$ longitude at an average elevation of about $1500 \mathrm{~m}$ asl (see figure 1). This place was earlier called 'Srinagari' or Purandhisthan. The city has unique physiographic setup with steep hills in the east and northeast, low lying paddy fields in the north, the floodplains of Jehlum in the south and west and raised plateau lands in the south. Srinagar city, under the jurisdiction of the Srinagar Municipal Corporation (SMC), now has an area of $227.41 \mathrm{~km}^{2}$ subdivided into 34 wards. The study area covers the oldest organic core part of Srinagar city (old downtown), the planned areas and even the unplanned new generation areas. This selected study area almost covers the biggest urban agglomeration and is the central part of Kashmir Valley in terms of social and economic aspects (Lawrence 1895). Over the years the city has witnessed massive urban growth.

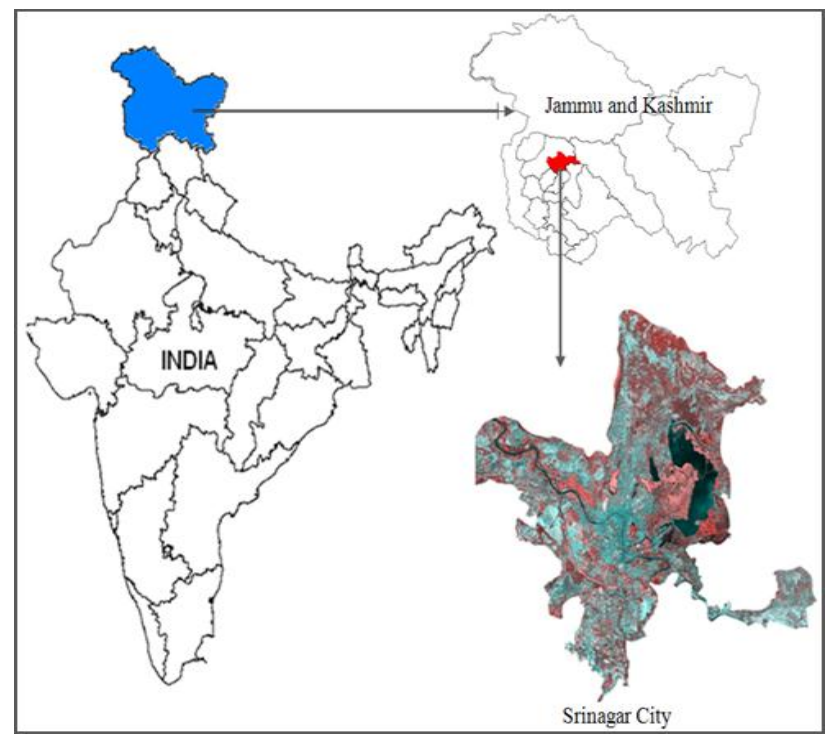

Figure 1. Location of Study Area

\section{MATERIALS AND METHODS}

The general approach for studying the dynamics of LULC change included primary and secondary data collection, generation of data layers and its analysis by standard geospatial and statistical techniques. The relevant information on urban sprawl and population growth was generated. Finally the forecast was obtained through the use of appropriate regression models. The detailed methodological flow diagram is presented in Figure 2.

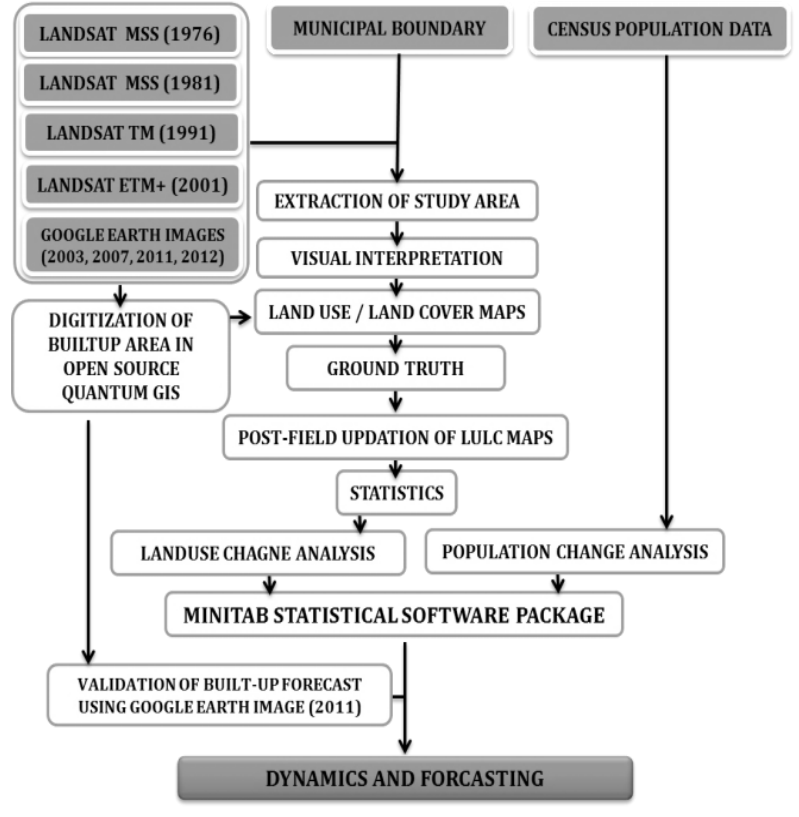

\subsection{Data sets}

Figure 2. Workflow of methods used

Urban sprawl and related land-use transformation studies require spatio-temporal data to evaluate LULC dynamics over the time period. Therefore, in the present study, the satellite images of LANDSAT MSS were used for the years 1972 and 1981; Landsat Thematic Mapper (TM) was used for the year 1991 and Landsat Enhanced Thematic Mapper Plus (ETM+) was used for the year 2001. In addition, Municipal city limits map from the Srinagar Municipal Corporation was used to extract the study area. The demographic details from the Census of India (1971, 1981, 1991, 2001 and 2011) were used to enable quantifying the increase in the population for nearly four decades.

\subsection{Data processing and preparation}

An on-screen visual interpretation technique was used to delineate the spatial extents of various LULC units. Primary focus was given to the built-up class (including constructed areas such as residential area, commercial complexes, institutions, roads, etc.), agriculture, horticulture, wetlands and water bodies. Elements of image interpretation - namely tone, texture, shape, size, pattern, location and association were used during the visual interpretation. The vectors derived from the digitization of various LULC units mapped from satellite images were checked for accuracy assessment of visual classification. Any wrong identification was corrected and the revised classification maps of LULC were used for the area calculation.

\subsection{Forecasting}

The results obtained from mapping and demographic data were statistically analyzed in Minitab Statistical Software Package. Appropriate regression models were fitted to project the increase in extend of built-up and population in future decades. The goal of regression analysis is to model the expected value of $\mathrm{y}$ as an $\mathrm{n}^{\text {th }}$ order polynomial, yielding the general polynomial regression model:

$$
y=a_{0}+a_{2} x+a_{2} x^{2}+a_{2} x^{x}+\cdots+a_{12} x^{n}+\mathrm{e}
$$


Conveniently, these models are all linear from the point of view of estimation, since the regression function is linear in terms of the unknown parameters $a_{0}, a_{1}$. Therefore, for least squares analysis, the computational and inferential problems of polynomial regression can be completely addressed using the techniques of multiple regression. This is done by treating $\mathrm{x}$, $\mathrm{x}^{2} \ldots$ as being distinct independent variables in a multiple regression model. Here $E$ denotes the error that is difference between predicted and actual values. The variables that were considered for the study included the change in built-up, agricultural land, water bodies and change in demographic data.

\subsection{Validation}

Google Image of 2011 was downloaded using Google Layers Plugin in Open Source Quantum GIS and only built-up areas were specifically digitized. The built-up area thus digitized was used to complement both validation and forecast of the results.

\section{RESULTS AND DISCUSSION}

\subsection{Population change}

The population census data of Srinagar city were collected between 1971 and 2011 to estimate change in population over the years. The analysis of the data revealed that the population in the region has increased by about $214.75 \%$. During the last century the city has grown 23.4 times in terms of spatial coverage and eight fold in population size (Bhat 2008). Population data and socioeconomic data have a direct relationship with urban growth (Sudhira et al. 2004). The state of Jammu and Kashmir has a population of 12.54 million out of which the population of Srinagar city has soared to about 1.26 million which alone constitutes $10 \%$ of the total population (see table 1). The population growth along the 5161 urban centers in the country is a thousand times more than in 1981 (Sivaramakrishna et al. 2005).

Table 1. Population growth over the years

\begin{tabular}{cccccc}
\hline Year & $\mathbf{1 9 7 1}$ & $\mathbf{1 9 8 1}$ & $\mathbf{1 9 9 1}$ & $\mathbf{2 0 0 1}$ & $\mathbf{2 0 1 1}$ \\
\hline Population & 403413 & 606002 & 800723 & 995806 & 1269751 \\
\hline
\end{tabular}

\subsection{Spatial Expansion of Srinagar City}

In Srinagar city 14 LULC classes were obtained by carrying out on-screen visual interpretation of satellite images of 1972, 1981, 1992 and 2001 (see table 2). Based on selective field checks, the overall classification accuracy of the LULC maps derived from the satellite images was determined, which ranged from $90 \%$ to $95 \%$. The Kappa coefficient ranged from 0.87 to 0.93. The area computations from temporal data indicated that the area under built-up in 1972, 1982, 1992 and 2004 was $18.10 \mathrm{~km}^{2}, 27.23 \mathrm{~km}^{2}, 41.80 \mathrm{~km}^{2}$ and $84.50 \mathrm{~km}^{2}$ respectively (see figure 3). Thus, over the years the amount of built-up land has grown by about $29.20 \%$, nearly three times the rate of population growth. The results showed that the rate of conversion of land to built-up in Srinagar City, is outstripping the rate of population growth. This implies that the land is consumed at excessive rates and probably in unnecessary amounts as well. The results also revealed that area under agriculture has drastically reduced by $11.65 \%$, followed by the plantation $8.35 \%$ and wetlands and water bodies by about $3.77 \mathrm{~km}^{2}$ and $1.49 \%$ respectively. The LULC classes least affected over the years included the barren land with no change and recreational areas with $0.07 \%$. The consumption of land obviously includes all development initiatives for commercial, industrial, residential, educational, and recreational establishments (Farooq and Ahmad 2008).

Table 2. Summarized LULC over the years and percent change in LULC

\begin{tabular}{|c|c|c|c|c|c|c|}
\hline \multirow{2}{*}{ S.No. } & \multirow{2}{*}{ Description } & \multicolumn{4}{|c|}{ Years } & \multirow{2}{*}{$\begin{array}{c}\text { Percent } \\
\text { Change } \\
\text { (1976- } \\
\text { 2001) } \\
\end{array}$} \\
\hline & & 1976 & 1981 & 1991 & 2001 & \\
\hline 1. & Agriculture & 83.55 & 80.59 & 78.12 & 57.06 & -11.65 \\
\hline 2. & Barren Land & 1.39 & 1.39 & 1.39 & 1.39 & 0.00 \\
\hline 3. & Built-up & 18.10 & 27.36 & 41.80 & 84.50 & 29.20 \\
\hline 4. & Forest & 5.70 & 5.56 & 5.52 & 2.94 & -1.21 \\
\hline 5. & Graveyard & 0.58 & 0.58 & 0.58 & 0.98 & 0.18 \\
\hline 6. & Horticulture & 22.82 & 20.59 & 18.60 & 15.98 & -3.01 \\
\hline 7. & Landfill & 0.23 & 0.93 & 1.00 & 1.03 & 0.35 \\
\hline 8. & Plantation & 41.54 & 40.80 & 35.73 & 22.54 & -8.35 \\
\hline 9. & Quarry & 0.21 & 0.21 & 0.21 & 1.20 & 0.44 \\
\hline 10. & Recreational & 1.89 & 1.99 & 2.00 & 2.05 & 0.07 \\
\hline 11. & Road & 0.32 & 0.52 & 0.56 & 0.83 & 0.22 \\
\hline 12. & Wasteland Scrub & 8.50 & 7.84 & 5.68 & 6.29 & -0.97 \\
\hline 13. & Waterbody & 14.92 & 13.92 & 12.49 & 11.54 & -1.49 \\
\hline 14. & Wetlands/Marshy & 27.66 & 25.14 & 23.74 & 19.09 & -3.77 \\
\hline Total & & 227.4 & 227.4 & 227.4 & 227.4 & \\
\hline
\end{tabular}

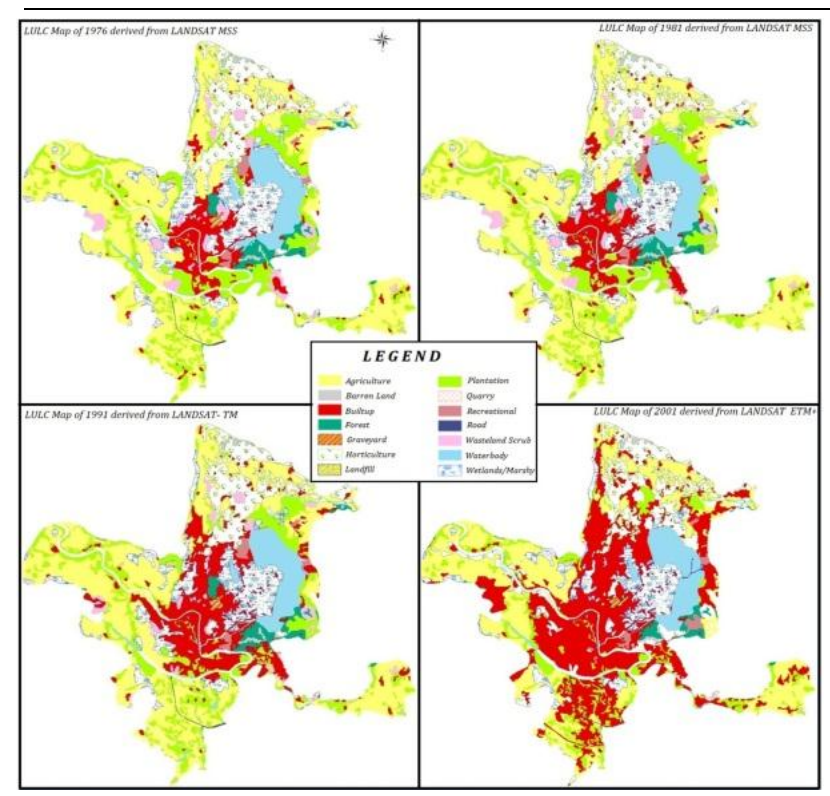

Figure 3. Three decadal variation in LULC of Srinagar City showing urban expansion

A unique approach was adopted by using high resolution satellite data from Google Earth to compliment both validation and forecast of built-up area. The trend analysis of moderate resolution satellite data of 1972, 1981, 1991 and 2001 forecasted the built-up area of about $124 \mathrm{~km} 2$ for the year 2011, while as the built-up area extracted from the Google image showed an area of $121 \mathrm{~km}^{2}$ for the same year (see figure 4), with percent error of $2.4 \%$. In order to make the forecast more valid, the built-up area figures from the Google Earth image was used as a 5th variable for future projections. This approach clearly validated the accuracy of future projections. The use of high resolution satellite data from Google earth is a relatively untapped new source of mapping and validation data for remote sensing studies (Knorn et al. 2009, Standart et al. 2011) spatial 
resolution of these images is high enough to allow clear visual interpretation of land cover especially the built-up as such they can be used as a validation data to aid evaluate classification in generating information.

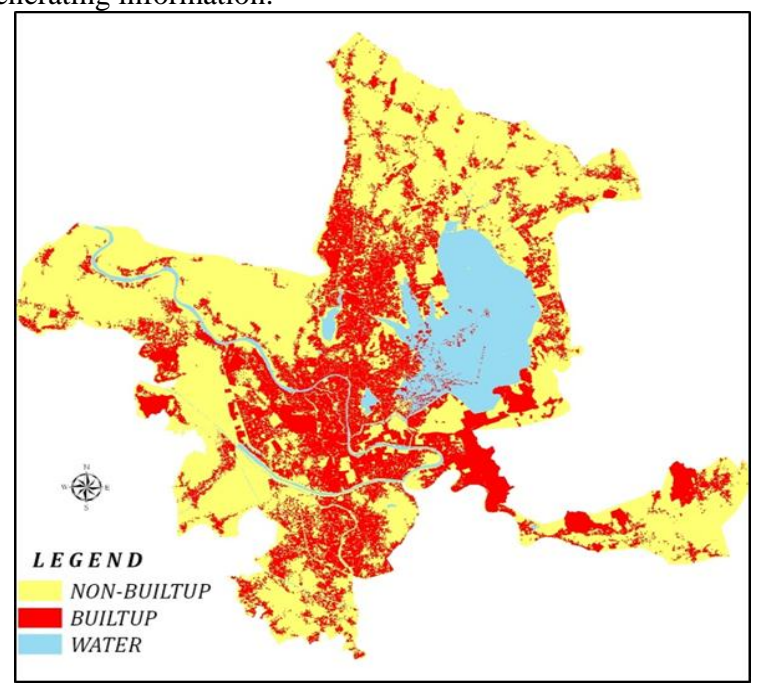

Figure 4. Built-up area delineated from Google Earth Image of 2011

\subsection{Common Conversions}

The study also revealed that, Srinagar is not only expanded in size but there is also a significant conversion of land between different LULC classes. The city has expanded on agricultural land, plantation areas, horticultural land, and also on wetland peripheries, resulting in heavy loss of fertile agricultural land, horticultural land and wetlands. The built-up has increased from $18.1 \mathrm{~km}^{2}$ in 1971 to $121.1 \mathrm{~km}^{2}$ in 2011 capturing land mainly from agriculture, plantation, horticulture and waterbodies/wetlands. The area under agriculture land and plantation has drastically decreased from $83.55 \mathrm{~km}^{2}$ and $41.54 \mathrm{~km}^{2}$ in 1971 to $57.06 \mathrm{~km}^{2}$ and $22.54 \mathrm{~km}^{2}$ in 2001 respectively. The fast intrusion of urban activities in the agricultural landscape of the peri-urban areas, from the spillover of the expanding population of Srinagar city caused by rapid urbanization has changed the occupational structure and the land-use pattern of urban fringe, creating negative impacts agricultural land (Nengroo 2011). The wetland/waterbodies has reduced in area from $42.58 \mathrm{~km}^{2}$ in 1971 to $30.63 \mathrm{~km}^{2}$ in 2001 . These current trends indicate that the conversion rates of agriculture, plantation, horticulture and wetlands/waterbodies were highest from1991-2001 with a net decrease of $21.06 \mathrm{~km}^{2}$, $13.19 \mathrm{~km}^{2}, 2.6 \mathrm{~km}^{2}$ and $5.7 \mathrm{~km}^{2}$ respectively. Urbanization is a process whereby productive agricultural lands, forests, surface water bodies and groundwater prospects are being irretrievably lost (Pathan et al. 1989, 1991). Increase in built-up has been always at the cost of adjacent LULC classes which mainly include agriculture, plantation and water bodies (Saravanan and Ilangovan, 2010, Shahab and Arshad, 2011, Humayun and Gowhar, 2008). The decrease in agriculture is most extensive and common feature for developing economies as urban extensions, industrial and other developments take place on the agricultural land (Nageswara Rao and Narendra, 2006).

\subsection{Analysis of Municipal Wards}

In order to understand the dynamics and spread of urbanization, the ward boundary obtained from Municipality was overlaid on the delineated LULC maps to have a better idea of the spread of built-up over the years. Wards are the sub-divisions of municipalities that are separate administrative units which limit the local elections. The Wards 01, 10, 11, 16, 17, 23, 24, 26, 29, and 30 owing to their $5-8 \mathrm{~km}$ proximity to the city center are heavily affected ones, while as Wards like 31, 32, 33, 28 and 25 are moderately affected (see figure 5). However, wards 12, 13, $14,15,19,26,27$, and 34 are comparatively less affected. These wards consist of fertile land for agricultural and horticultural purpose. The trend shows that less affected wards are now being rapidly infiltrated for residential purpose owing to the low-cost of land and moderate distance from city center (Figure 6). Also, the older parts of the city have become increasingly congested resulting in the haphazard expansion, covering most of the agricultural land on the fringes of the city. The result also showed that increase in built-up during 1972-2011 is more in outer periphery zone i.e. $5 \mathrm{~km}$ to $7 \mathrm{~km}$.

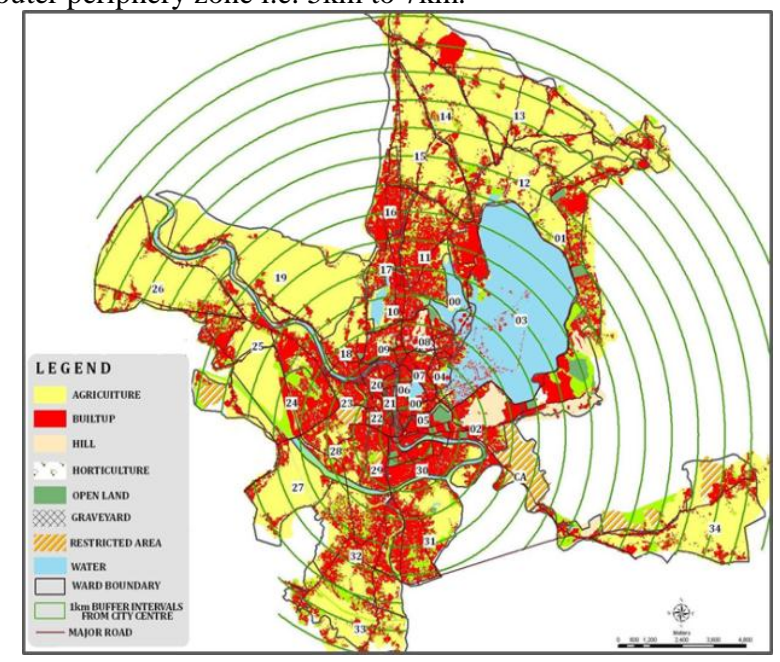

Figure 5. Ward-wise sprawl of built-up area

Presence of water-bodies like Dal Lake, Nagin Lake, Anchar Lake and Zabarwan Hills within the city though has restricted the sprawl to a major extent. However, within Dal-lake there has been a significant increase in the built-up area. Topographical limitations such as hilly areas, the mountain peaks, marshy area and water bodies generally restrict the urban expansion and the general trend of expansion remained confined to plain areas (Shahab and Arshad 2011).

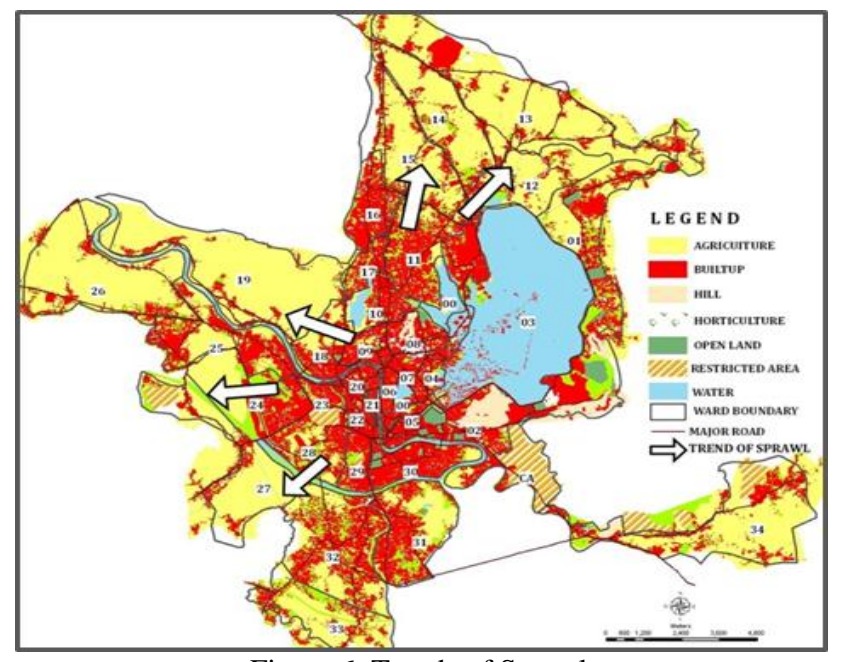

Figure 6. Trends of Sprawl

Presence of water-bodies like Dal Lake, Nagin Lake, Anchar Lake and Zabarwan Hills within the city though has restricted the sprawl to a major extent. However, within Dal-lake there has been a significant increase in the built-up area. 
Topographical limitations such as hilly areas, the mountain peaks, marshy area and water bodies generally restrict the urban expansion and the general trend of expansion remained confined to plain areas (Shahab and Arshad, 2011).

\subsection{Population and land cover forecasting}

The results obtained from the LULC mapping for built-up change over the years were correlated with the increase in population, with coefficient of correlation of 0.971 . The increase in both classes seemed to be positively correlated. The scatter plot of the observed built-up and population change is given in Figure 7 and 8.

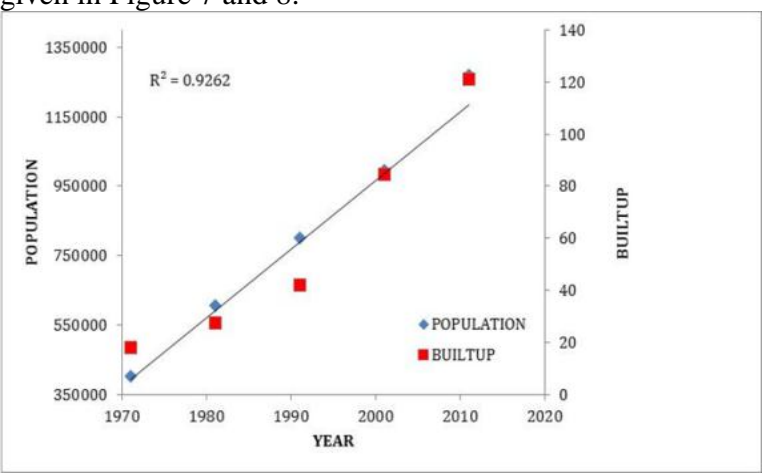

Figure 7. Scatter plot of observed built-up and population change

Various trend models were used to study the behavior of builtup and population. It was observed that the best result was given by a polynomial of the third order with $y=-0.000 x^{3}+5.733 x^{2}-11531 x+8 E+06 \& R^{2}=$

\subsection{3}

$$
\begin{aligned}
& \text { for the population } \quad \text { growth } \\
& y=-7.227 x^{3}-43068 x^{2}+9 E+07 x-6 E+10 \& R^{2}= \\
& 0.99
\end{aligned}
$$

fitted the better for the built-up change (see figure 7 and 8). Hence from the results it can be inferred that over the years the population has significantly increased which has been reflected by the increase in the built-up.

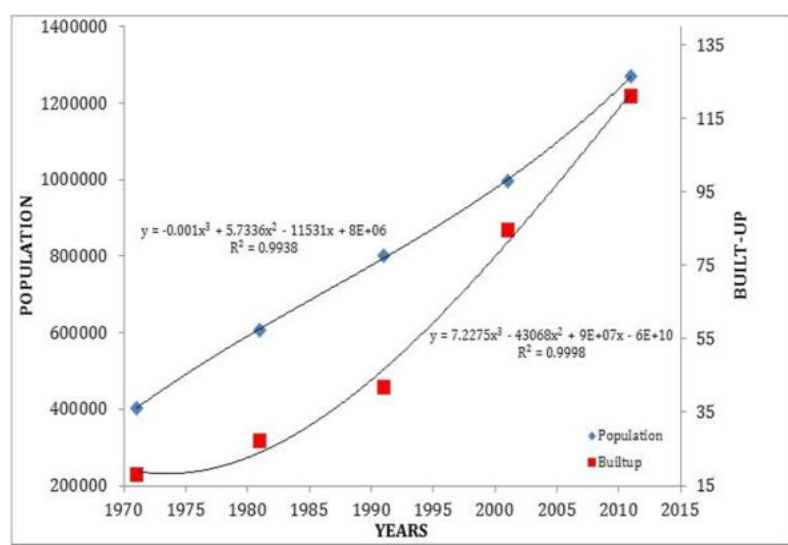

Figure 8. Trends of built-up and population change

In addition to the trend analysis, forecasting was done on a decadal basis by using regression models for built-up and population up to the year 2031. The results revealed that population is estimated to increase 1.52 million by 2021 and 1.83 million by 2031 (see figure 9a). While as, built-up is estimated to increase $179.02 \mathrm{~km}^{2}$ in 2021 and $246.84 \mathrm{~km}^{2}$ in 2031 respectively (see figure $9 \mathrm{~b}$ ). The results of projected population and built-up are shown in Table (3).

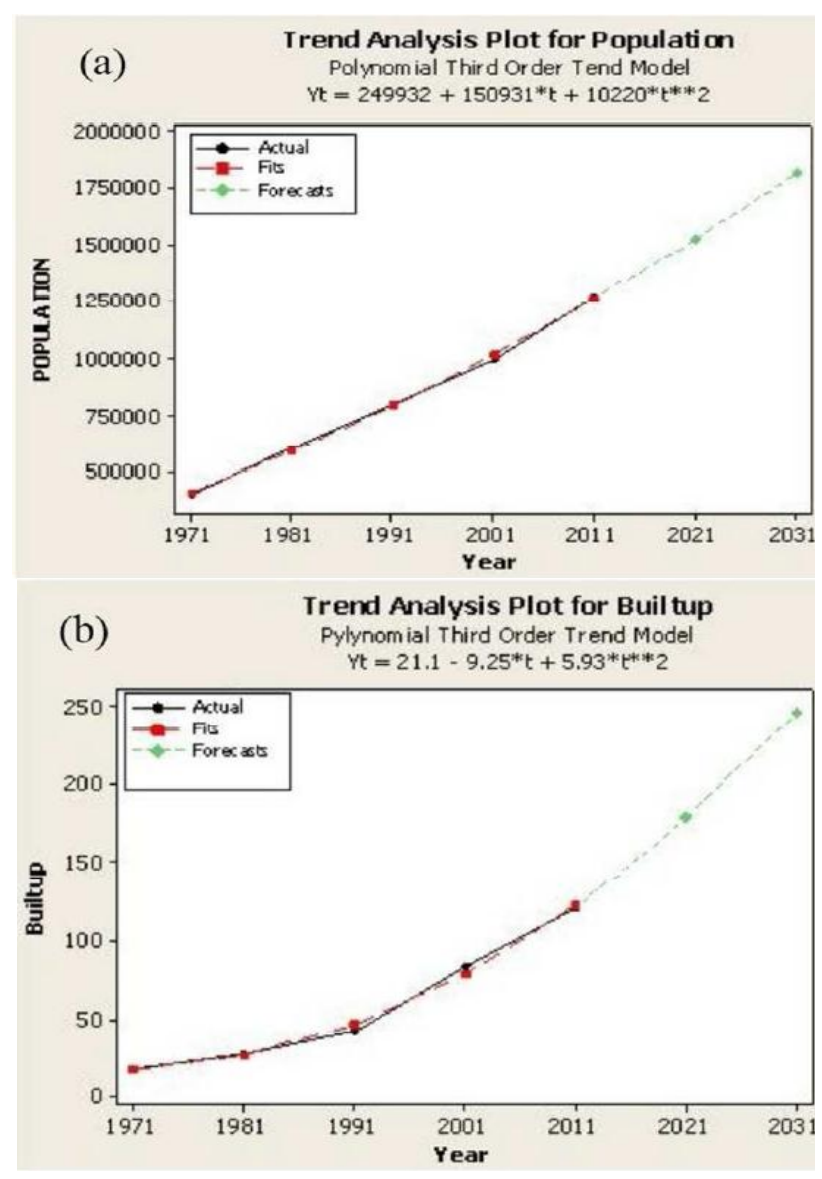

Figure 9(a \& b). Forecast for population and built-up using Polynomial Third-Order Trend Model

The projected figures clearly indicate that the area under builtup will move beyond the carrying capacity of Srinagar City, as the city itself has an area of $227.41 \mathrm{~km}^{2}$ of which nearly $31 \mathrm{~km}^{2}$ are under water bodies and wetlands. The percent increase in built-up revealed that built-up had increased the maximum in the year 2001 by $102.1 \%$ and is projected to increase by $39.4 \%$ and $37.8 \%$ from year 2021 and 2031 respectively (see table 4). The forecast was limited only up to 2031 as the threshold limit for carrying capacity of the city reached its maximum. The forecast for 2021 and 2031 (see table 5) show similar results with a net decrease in agricultural $\left(35.34 \mathrm{~km}^{2} \& 44.39 \mathrm{~km}^{2}\right)$, plantation $\left(24.87 \mathrm{~km}^{2} \& 31.11 \mathrm{~km}^{2}\right)$, horticulture $\left(2.84 \mathrm{~km}^{2}\right.$ \& $\left.3.03 \mathrm{~km}^{2}\right)$ and wetlands/waterbodies $\left(6.98 \mathrm{~km}^{2} \& 8.02 \mathrm{~km}^{2}\right)$. The trend models have been successfully used to predict population and urban growth in many studies (Monalisha et al. 2006). During 1971-1981, the rate of growth for built-up area was $51.1 \%$, while as the population increased by $50.2 \%$. During 1981-1991, the urban area expanded by $52.7 \%$ while the population increased by $32.1 \%$. The forecasting using present trends has shown that the rate of urban growth usually outnumbers the population growth (Jat et al. 2011, Mohan et al. 2008). The most remarkable tendency towards sprawl development was witnessed in the 1990s decade period when the city area grew by $102.1 \%$ while the population increased by $24.3 \%$. The predicted rate of growth during 2011-2021 and $2021-2031$ in the built-up area is estimated to be $65.6 \%$ while the population is estimated to increase by $19.9 \%$ and $18.6 \%$ respectively. As can be appreciated from the forecast the rate of development of land in Srinagar is currently in excess of the population growth. 
Table 3: Sprawl metrics and population of Srinagar City

\begin{tabular}{|c|c|c|c|c|}
\hline \multirow[b]{2}{*}{ Year } & \multirow[b]{2}{*}{ Population } & \multicolumn{3}{|c|}{ Built-up } \\
\hline & & Total $\left(\mathbf{k m}^{2}\right)$ & Increase from previous decade & $\begin{array}{l}\text { Percent } \\
\text { Increase }\end{array}$ \\
\hline 1971 & $4,03,413$ & 18.1 & - & - \\
\hline 1981 & $6,06,002$ & 27.3 & 9.2 & 51.1 \\
\hline 1991 & $8,00,723$ & 41.8 & 14.4 & 52.7 \\
\hline 2001 & $9,95,806$ & 84.5 & 42.7 & 102.1 \\
\hline 2011 & $12,69,751$ & 121.1 & 43.6 & 51.9 \\
\hline 2021 & $15,23,420$ & 179.02 & 84.2 & 65.6 \\
\hline 2031 & $18,07,205$ & 246.84 & 139.6 & 65.6 \\
\hline
\end{tabular}

Table 4: Sprawl metrics and increase rates in urban area and population of Srinagar city

\begin{tabular}{lcccc}
\hline & \multicolumn{3}{c}{ Population } & Built-up \\
\cline { 2 - 5 } Period & Net Increase & Percent Increase & Net Increase & Percent Increase \\
\hline $\mathbf{1 9 7 1 - 1 9 8 1}$ & $2,02,589$ & 50.2 & 9.2 & 51.1 \\
$\mathbf{1 9 8 1 - 1 9 9 1}$ & $1,94,721$ & 32.1 & 14.4 & 52.7 \\
$\mathbf{1 9 9 1 - 2 0 0 1}$ & $1,95,083$ & 24.3 & 42.7 & 102.1 \\
$\mathbf{2 0 0 1 - 2 0 1 1}$ & $2,73,945$ & 27.5 & 43.9 & 51.9 \\
$\mathbf{2 0 1 1 - 2 0 2 1}$ & $2,53,669$ & 19.9 & 84.2 & 65.6 \\
$\mathbf{2 0 2 1 - 2 0 3 1}$ & $2,83,785$ & 18.6 & 139.6 & 65.6 \\
\hline
\end{tabular}

Table 5: Change Metrics in Agriculture, Horticulture and Wetlands of Srinagar city

\begin{tabular}{|c|c|c|c|c|c|c|c|c|}
\hline & \multicolumn{2}{|c|}{ Agriculture } & \multicolumn{2}{|c|}{ Plantation } & \multicolumn{2}{|c|}{ Horticulture } & \multicolumn{2}{|c|}{ Wetlands/Waterbodies } \\
\hline & $\begin{array}{r}\text { Total } \\
\left(\mathrm{km}^{2}\right) \\
\end{array}$ & $\begin{array}{c}\text { Net } \\
\text { Decrease }\end{array}$ & $\begin{array}{c}\text { Total } \\
\left(\mathrm{km}^{2}\right)\end{array}$ & $\begin{array}{c}\text { Net } \\
\text { Decrease }\end{array}$ & $\begin{array}{r}\text { Total } \\
\left(\mathbf{k m}^{2}\right) \\
\end{array}$ & $\begin{array}{c}\text { Net } \\
\text { Decrease }\end{array}$ & $\begin{array}{r}\text { Total } \\
\left(\mathrm{km}^{2}\right)\end{array}$ & $\begin{array}{c}\text { Net } \\
\text { Decrease }\end{array}$ \\
\hline 1971 & 83.55 & & 41.54 & & 22.82 & & 42.58 & \\
\hline 1981 & 80.59 & -2.96 & 40.8 & -0.74 & 20.59 & -2.23 & 39.06 & -3.52 \\
\hline 1991 & 78.12 & -2.47 & 35.73 & -0.19 & 18.6 & -1.99 & 36.23 & -2.83 \\
\hline 2001 & 57.06 & -21.06 & 22.54 & -13.19 & 15.98 & -2.62 & 30.63 & -5.6 \\
\hline 2011 & 31.72 & -25.34 & 4.07 & -18.47 & 13.38 & -2.6 & 24.855 & -5.775 \\
\hline 2021 & -3.62 & -35.34 & -20.8 & -24.87 & 10.54 & -2.84 & 17.867 & -6.98 \\
\hline 2031 & -48.01 & -44.39 & -51.91 & -31.11 & 7.51 & -3.03 & 9.839 & -8.02 \\
\hline
\end{tabular}

\section{CONCLUSIONS}

One of the potential threats to sustainable development is urban growth, were urban planning with effective resource utilization, allocation of natural resources and infrastructure initiatives are key concerns. In this study an attempt has been made to understand the urban growth of Srinagar city, using multitemporal satellite and population data and modeling the same for future prediction. The spatial data along with the attribute data of the region aided in analyzing statistically the urban growth form and its pattern. It was found that the change in built-up area over the period of nearly 40 years is $585.08 \%$, and by 2031 the built-up area in the region would rise to $246.84 \mathrm{~km}^{2}$, which is beyond the carrying capacity of the Srinagar City. The population is set to increase by 1.83 million in 2031. The rate of urban growth would be about three times the population growth, if projected using the past trend. The area under agriculture land has drastically decreased from $83.55 \mathrm{~km}^{2}$ in 1971 to $57.06 \mathrm{~km}^{2}$ in 2001 respectively. The forecast for 2031 show a net decrease of $44.39 \mathrm{~km}^{2}$ in agricultural land. The estimates of the regression model seem to predict the results with the reliable accuracy as validated from the Google earth data. Thus, it can be used as an efficient tool to obtain reliable forecasts. The urban expansion of the city has destroyed fertile agricultural land and productive horticultural land which cannot be recovered, and the study area is losing agrarian characteristics. Many wetland ecosystems have been disturbed.
The current trend of sprawl towards peripheral wards demands a state of the art planning approach as people in this part of the world prefer individual households instead of the joint flat system. Although urban expansion cannot be stopped, with proper management and planning it can be restricted and directed in a desirable and sustainable way, protecting fertile agricultural lands. There needs to be a stricter implementation of agricultural land conversion laws and greater encouragement for farmers to remain in farming activities.

\section{REFERENCES}

Barnes, K.B., Morgan, J.M. III, Roberge, M.C. and Lowe, S., 2001. Sprawl development: its patterns, consequences, and measurement. Towson University. Available online at: http://chesapeake.towson.edu/landscape/urbansprawl/download/ Sprawl_white_paper.pdf (accessed 29 November 2011).

Batty, M., Xie, Y. and Sun, Z., 1999. The dynamics of urban sprawl. Working Paper Series, Paper 15, Center for Advanced Spatial Analysis, University College London. Available online at: http://www.casa.ucl.ac.uk (accessed 29 November 2011).

Bhat, M. S., 2008. Urban System in Himalayas, Arina Publishers and Distributors, New Delhi.

Census of India, 1991\&2001. (http://www.censusindia.net). 
Cheng, J. and Masser, I., 2003. Urban growth pattern modeling: a case study of Wuhan City, PR China. Landscape Urban Planning, 62, pp. 199-217.

Dekoning, G.H.J., VeldkamP, A. and Fresco, L.O., 1998. Land use in Ecuador: a statistical analysis at different aggregation levels. Agriculture Ecosystems and Environment, 70, pp. 231247.

Dendoncker, N., Schmit, C. and Rounsevell, M., 2008. Exploring spatial data uncertainties in land-use change scenarios. International Journal of Geographical Information Science, 22(9), pp. 1013-1030.

Epstein, J., Payne, K., and Kramer, E., 2002. Techniques for mapping suburban sprawl. Photogrammetric Engineering and Remote Sensing, 63(9), pp. 913-918.

Farooq, S. and Ahmad, S., 2008. Urban Sprawl Development around Aligarh City: A Study Aided by Satellite Remote Sensing and GIS. Journal of Indian Society of Remote Sensing, 36 , pp. $77-88$.

Fung, T. and Ledrew, E., 1987. Application of principal components analysis in change detection. Photogrammetric Engineering \& Remote Sensing, 53(12), pp. 1649-1658.

Hurd, J. D., Wilson, E. H., Lammey, S. G., and Civco, D. L., 2001. Characterization of forest fragmentation and urban sprawl using time sequential Landsat Imagery. In: ASPRS Annual Convention, St. Louis, MO. April 23-27.

Howard, S. M., 1986, Use of AVHRR Data in an Information System for Fire Management in the Western United States. In: International Symposium on Remote Sensing of Environment, 20th, Nairobi, Kenya, December, 1, pp. 67-79.

Jat, M.K., Garg P.K. and Khare D., 2008, Modeling of urban growth using spatial analysis techniques: a case study of Ajmer city (India), International Journal of Remote Sensing, 29, pp. 543-567.

Jothimani, P., 1997. Operational urban sprawl monitoring using satellite remote sensing: excerpts from the studies of Ahmedabad, Vadodara and Surat, IndiaIn: 18th Asian Conference on Remote Sensing, October 20-24, Malaysia.

Knorn, J., Rabe, A., Radeloff, V.C., Kuemmerle, T., Kozak, J. and HosterT, P., 2009, Land cover mapping of large areas using chain classification of neighboring Landsat satellite images. Remote Sensing of Environment, 113, pp. 957-964.

Lata K. M., Sankarrao C. H., Krishna Prasad V., Badrinath K. V. S. and Raghavaswamy, 2001, Measuring urban sprawl: a case study of Hyderabad. GIS development, 5(12).

Lawrence, W. R., 1895. Valley of Kashmir. Henry Frowde, Oxford University Press.

Li, X., and Yeh, A.G.O., 1998. Principal Component Analysis of Stacked Multi-Temporal Images for Monitoring of Rapid Urban Expansion in the Pearl River Delta. International Journal of Remote Sensing, 19(8), pp. 1501-1518.

Liu, S., Sylvia, P. and Li, X., 2002. Spatial patterns of urban land use growth in Beijing. Journal of Geographical Sciences, 12(3), pp. 266-274.
Nelson, R. F., 1983. Detecting forest canopy change due to insect activity using Landsat MSS. Photogrammetric Engineering and Remote Sensing, 49, pp. 1303-1314.

Mohan M., Pathan, S.K., Narendrareddy K., Kandya A. and Pandey S., 2011. Dynamics of Urbanization and Its Impact on Land-Use/Land-Cover: A Case Study of Megacity Delhi. Journal of Environmental Protection, 2, pp. 1274-1283.

Monalisha M., KamaL K.M. and Subudhi A.P., 2011. Urban Sprawl Mapping and Land Use Change Analysis Using Remote. Sensing and GIS: Case Study of Bhubaneswar city, Orissa. Available online at: http: www.geospatialworldform.org/2011/proceedings/pdf/Monalisha .pdf (accessed 29 November 2011).

Nageswararao, K. and Narendra, K., 2006. Mapping and evaluation of urban sprawling in the Mehadrigedda watershed in Visakhapatnam metropolitan region using remote sensing and GIS. Current Science, 1552(91), pp. 1552-1557.

Nengroo, Z. A., 2011. Dynamics of land use change in ruralurban fringe - a case study of Srinagar City. M. Phill. Dissertation, University of Kashmir, Hazratbal, India.

Pathan, S.K., Jothimani, P., Pendharkar, S.P. and Kumar, D.S., 1989, Urban land use mapping and zoning of Mombay Metropolitan region using remote sensing data. Journal of Indian Society of Remote Sensing, 17, pp. 11-22.

Pathan, S.K., Shukla, V.K., Patel, R.G. and Mehta, K.S., 1991. Urban land use mapping - a case study of Ahmedabad city and its environs. Journal of Indian Society of Remote Sensing, 19, pp. 95-112.

Peng, J., Wu, J., Yin, H., Li, Z., Chang, Q. and Mu, T., 2008, Rural land use change during 1986-2002 in Lijiang, China, based on remote sensing and GIS data. Sensors, 8, pp. 82018223 .

Pilon, P.G., Howard, P.J. and Bullock, R.A., 1988, An enhanced classification approach to change detection in semi arid environment. Photogrammetric Engineering and Remote Sensing, 54, pp. 1709-1716.

Pontius JR., R. G. and Schneider, L. C., 2001, Land-cover change model validation by an ROC method for the Ipswich watershed, Massachusetts, USA. Agriculture, Ecosystems and Environment, 85, pp. 239-248.

Rashid, H., and Naseem, G., 2007. Quantification of Loss in Spatial Extent and Wetlands in the Suburbs of Srinagar City during Last Century Using Geospatial Approach. In: M. Sengupta and R. Dalwani, Eds., Proceedings of Taal 2007: The 12th World Lake Conference, pp. 653-658.

Saravanan, P. and Ilangovan, P., 2010. Identification of Urban Sprawl Pattern for Madurai Region Using GIS. International Journal of Geomatics and Geosciences. 1(2), pp. 144-149.

Serneels, S. and Lambin, E. F., 2001. Proximate causes of landuse change in Narok District, Kenya: a spatial statistical model. Agriculture Ecosystems and Environment, 85, pp. 6581. 
Shahab, F., and Arshad, A. 2011. Impact of Urban Land Transformation on Water Bodies in Srinagar City, India. Journal of Environmental Protection, 2, pp. 142-153.

Shekhar.S., 2004. Urban Sprawl Assessment: Entropy Approach", GIS Development, 8(5), pp. 43-48

Shen, G., 2002. Fractal dimension and fractal growth of urbanized areas. International Journal of Geographic Information Systems, 16(5), pp. 419-437.

Sivaramakrishna K. C., Kundu A. and Singh B.N., 2005. Handbook of Urbanization in India. Oxford University Press, New Delhi, pp. 177.

Standart, G.D., Stulken, K.R., Zhang, X. and Zong, Z.L., 2011. Geospatial visualization of global satellite images with VisEROS. Environmental Modelling Software, 26, pp. 980-982.

Sudhira, H.S., Ramachandra, T.V. and Jagdish, K.S., 2004. Urban sprawl: metrics, dynamics and modelling using GIS. International Journal of Applied Earth Observation and Geoinformation, 5, pp. 29-39.

Theobald, D. M., 2001. Quantifying urban and rural sprawl using the sprawl index". Paper presented at the Annual Conference of the Association of American Geographers in New York.

Torrens P. M. and Alberti M., 2000. Measuring sprawl. Working paper no. 27, Centre for Advanced Spatial Analysis, University College London.
Toll, D.L., 1980. Urban Area Update Procedures Using Landsat Data. In: Proceedings of the American Society of Photogrammetry. 5410 Grosvenor Lane, Bethesda, MD 208142160.

Trexler, J.C., and Travis, J., 1993. Nontraditional regression Analysis. Ecology. 74(6), 1629-1637.

Veldkamp, A., and Fresco, L.O., 1996. CLUE: A conceptual model to study the conversion of land use and its effects. Ecological Modelling, 85, pp. 253-270.

Webster, C.J., 1995. Urban morphological fingerprints. Environment and planning , 22, pp.279-297.

Wilson, E.H., Hurd, J.D., Civco, D.L., Prisloe, M.P. and Arnold, C., 2003. Development of a geospatial model to quantify, describe and map urban growth. Remote Sensing of Environment, 86, pp. 275-285.

Yeh, A. G. O. and Xia LI., 2001. Measurement and monitoring of urban sprawl in a rapidly growing region using entropy. Photogrammetric Engineering and Remote Sensing, 67(1), pp. 83.

Zeug, G. and Eckert, S., 2010. Population Growth and Its Expression in Spatial Built-up Patterns: The Sana'a, Yemen Case Study. Remote Sensing, 2, pp. 1014-1034 